\title{
Erratum to: Patterns of recruitment and microhabitat associations for three predatory coral reef fishes on the southern Great Barrier Reef, Australia
}

\author{
C. K. C. Wen · M. S. Pratchett - G. R. Almany • \\ G. P. Jones
}

Published online: 3 February 2013

(c) Springer-Verlag Berlin Heidelberg 2013

Erratum to: Coral Reefs

DOI 10.1007/s00338-012-0985-x

A discrepancy has been noted in Fig. 2.
The Plectropomus leopardus should be listed Plectropomus maculatus, same as other coral trout name in this article.

The online version of the original article can be found under doi:10.1007/s00338-012-0985-x.

C. K. C. Wen · G. P. Jones

School of Marine and Tropical Biology, James Cook University,

Townsville, QLD 4814, Australia

C. K. C. Wen · M. S. Pratchett $(\bowtie) \cdot$ G. R. Almany •

G. P. Jones

ARC Centre of Excellence for Coral Reef Studies,

James Cook University, Townsville, QLD 4814, Australia

e-mail: morgan.pratchett@jcu.edu.au 